\title{
17. NORTH ATLANTIC QUATERNARY SILICOFLAGELLATES, DEEP SEA DRILLING PROJECT LEG 941
}

\author{
David Bukry, U.S. Minerals Management Service, Scripps Institution of Oceanography²
}

\begin{abstract}
Quaternary silicoflagellates from Deep Sea Drilling Project (DSDP) Mid-Atlantic Leg 94 are generally sparse and dissolution-thinned. Mesocena quadrangula, a low-latitude biostratigraphic guide species, occurs at all four sites studied $(606,607,609$, and 611), allowing identification of low-latitude zones-Dictyocha aculeata Zone, Mesocena quadrangula Zone, and Dictyocha stapedia stapedia Zone. A lack of cool-water Distephanus speculum speculum reflects warm relative paleotemperature values (Ts 74 to 98) for Leg 94. Comparison with assemblages at coastal DSDP Hole 397, off Africa, shows that Hole 397 has more abundant D. speculum speculum, suggesting that upwelling nutrient supply may significantly affect the total numbers of this species. The siliceous record of Leg 94 is sporadic, with several levels of nonpreservation that make paleotemperature trends difficult to establish by silicoflagellates. The northern range of $M$. quadrangula is extended to $52^{\circ} 50^{\prime} \mathrm{N}$ at Hole $611 \mathrm{C}$. Opal phytoliths occur at southern Holes 606 and 607 . These grasslands-produced nannofossils, representing eolian sedimentation from northwestern Africa, were likely distributed most widely during arid glacial intervals.
\end{abstract}

\section{INTRODUCTION}

Leg 94 in the North Atlantic Ocean was designed to study the late Cenozoic sedimentologic and micropaleontologic record of changing paleoclimatic conditions from a series of hydraulic piston cores recovered between $37^{\circ} \mathrm{N}$ and $53^{\circ} \mathrm{N}$. Quaternary silicoflagellates were studied in the eastern North Atlantic along a south to north transect formed by DSDP Holes 606, 607, 609, and 611C to determine the northern and southern limits of taxa, for comparison with other North Atlantic and North Pacific sites. A primary interest was to establish the northern range of Mesocena quadrangula, a key mid-Quaternary biostratigraphic guide at low latitude. An opportunity to test the utility in the Atlantic Ocean of the relative paleotemperature model for silicoflagellates that was developed in the Pacific Ocean was also presented by the translatitudinal array of core holes for Leg 94 (Fig. 1).

\section{METHODS AND MATERIALS}

Standard acid-residue processing of 34 samples of the generally carbonate-rich sediment of Leg 94 was done using concentrated $\mathrm{HCl}$, $\mathrm{H}_{2} \mathrm{O}_{2}$, heating, and distilled-water rinses. Decanting, instead of sieving, was done to preserve the original size distribution of siliceous microfossil suites. Light-microscope strewn slides were studied at a magnification of $500 \times$, because dissolution thinning makes silicoflagellates difficult to discern in Piccolyte mounting medium at lower magnifications. Mechanical stage traverses of whole slide areas of $22 \mathrm{~mm} \times 40$ $\mathrm{mm}$ to a count of 300 were attempted, but typical counts were terminated at counts of 50,100 , or 200 on slides where silicoflagellates were evidently too sparse. Low-latitude silicoflagellate zones for the Quaternary (Bukry, 1981a) were applicable for the assemblages from Leg 94 because of the presence of marker species, such as Dictyocha aculeata, Mesocena quadrangula, and Octactis pulchra.

\footnotetext{
${ }^{1}$ Ruddiman, W. F., Kidd, R. B., Thomas, E., Init. Repts. DSDP, 94: Washington (U.S Govt, Printing Office)

2 Address: U.S. Minerals Management Service (A-015), Scripps Institution of Oceanography, La Jolla, CA 92093.
}

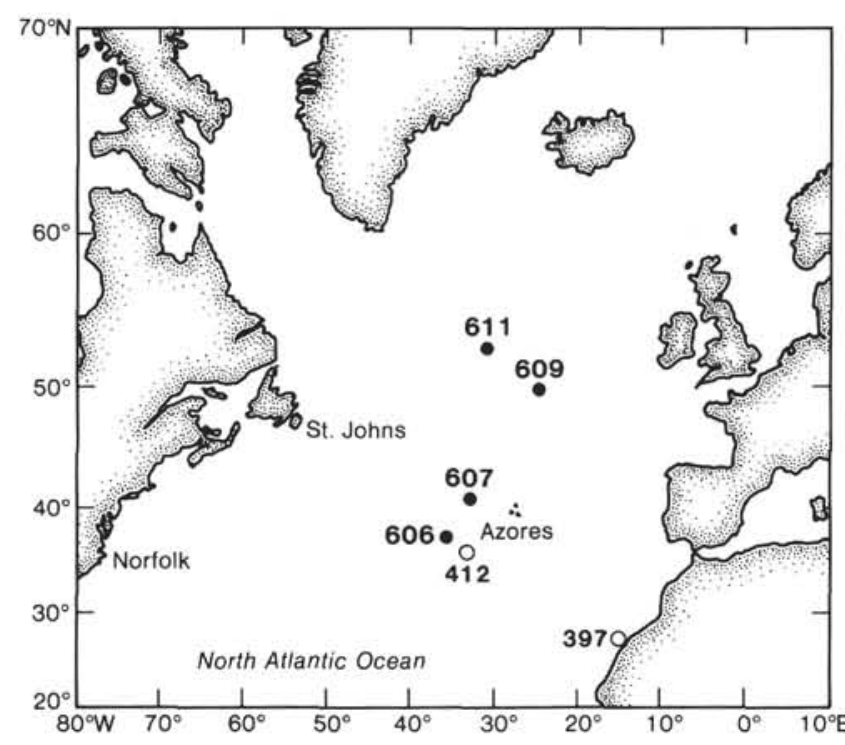

Figure 1. Location of Leg 94 sites (circular disks) and other DSDP key North Atlantic Quaternary silicoflagellate sites (open circles). Leg 94 departed Norfolk in June, 1983 and arrived at St. Johns in August, 1983.

\section{HOLE SUMMARIES}

\section{Hole 606}

\section{$\left(37^{\circ} 20.32^{\prime} \mathrm{N}, 35^{\circ} 29.99^{\prime} \mathrm{W}\right.$, water depth $3007 \mathrm{~m}$ )}

Hole 606 , on the western flank of the Mid-Atlantic Ridge, was cored by a newly designed hydraulic piston corer to provide a Neogene reference section with minimal drilling disturbance from the northern part of the modern subtropical gyre. This hole was needed for comparison with glacial-interglacial paleoceanography at more northerly DSDP holes. Several previous DSDP holes occur nearby, including Holes 333 to 335 (Leg 37), Hole 
412 (Leg 49), and Hole 558 (Leg 82), but all these were cored by more disruptive rotary coring. Hole 335 is the closest, only $27 \mathrm{~km}$ to the southeast. Aside from Hole 412 , Quaternary silicoflagellate occurrences are minor.

Silicoflagellates are sparse to common in Quaternary Cores 606-2 to 606-4 and are extensively thinned by dissolution. Diversity is highest in the older samples, and high relative paleotemperatures are indicated by the low abundance of hexagonal Distephanus (Table 1).

Silicoflagellates are most abundant in Sample 606-3-5, $100-102 \mathrm{~cm}(19 \mathrm{~m})$, which is assigned to the Quaternary Mesocena quadrangula Zone. The warm-water assemblage is dominated by Dictyocha. An unusual, small, circular variety of Mesocena quadrangula actually outnumbers normal specimens, $5 \%$ to $2 \%$. Some spines of the small variety are so short that the specimens would be difficult to distinguish from Mesocena circulus, were it not for the presence of other clearly transitional specimens with spines.

The presence of eolian sediment from northwestern Africa is indicated by the presence of festucoid and panicoid opal phytoliths and the nearshore and nonmarine diatom genus Melosira (Bukry, 1979a) in the silicoflagellate fraction of samples from Hole 606. Abundance levels of the biogenic eolia are, however, very low, with concentrations of less than 5 per 100 silicoflagellates. This presence of identifiable biogenic eolia at the MidAtlantic Ridge suggests additional evidence for the periods of strong transport of eolia from Africa to elevated mid-ocean locations.
The best silicoflagellate sequence of the nearby DSDP holes occurs in Hole $412\left(36^{\circ} 33.74^{\prime} \mathrm{N}, 33^{\circ} 09.96^{\prime} \mathrm{W}\right.$, $2609 \mathrm{~m}$ ), which also contains noteworthy concentrations of biogenic eolia (Bukry, 1979b). The assemblages of Hole 412 are also similar to those of Hole 606 in the numerical dominance of Dictyocha aculeata and D. stapedia stapedia. Also, the small numbers of Distephanus speculum speculum and Mesocena quadrangula yield similarly high relative paleotemperature values; however, the temperate species Dictyocha hessii and D. lingii are less abundant at Hole 606 than at more easterly Site 412 .

\section{Hole 607}

\section{$\left(41^{\circ} 00.07^{\prime} \mathrm{N}, 32^{\circ} 57.44^{\prime} \mathrm{W}\right.$, water depth $\left.3427 \mathrm{~m}\right)$}

Hole 607 was cored on the western flank of the MidAtlantic Ridge northwest of the Azores to obtain an upper Cenozoic sedimentary record near the northern limit of the modern subtropical gyre. Hole 607 lies at the northern end of the cluster of DSDP sites located on the MidAtlantic Ridge between $30^{\circ}$ and $40^{\circ} \mathrm{N}$. Quaternary silicoflagellates studied from Cores 607-3 to 607-7 are thinned by dissolution but are fairly diverse. The Mesocena quadrangula Zone is identified in Cores 607-4 to 607-6 by Dictyocha lingii and Mesocena quadrangula (Table 1). A large abundance acme of $M$. quadrangula at $35 \%$ in Sample $607-6-2,100-102 \mathrm{~cm}(47 \mathrm{~m})$ serves as a guide to the Jaramillo magnetic event. The relative paleotemperature values of Hole 607 are lower than for Hole 606,

Table 1. Percentage occurrences of silicoflagellates in Quaternary sediment from DSDP Leg 94 (Holes 606, 607, 609, and 611C).

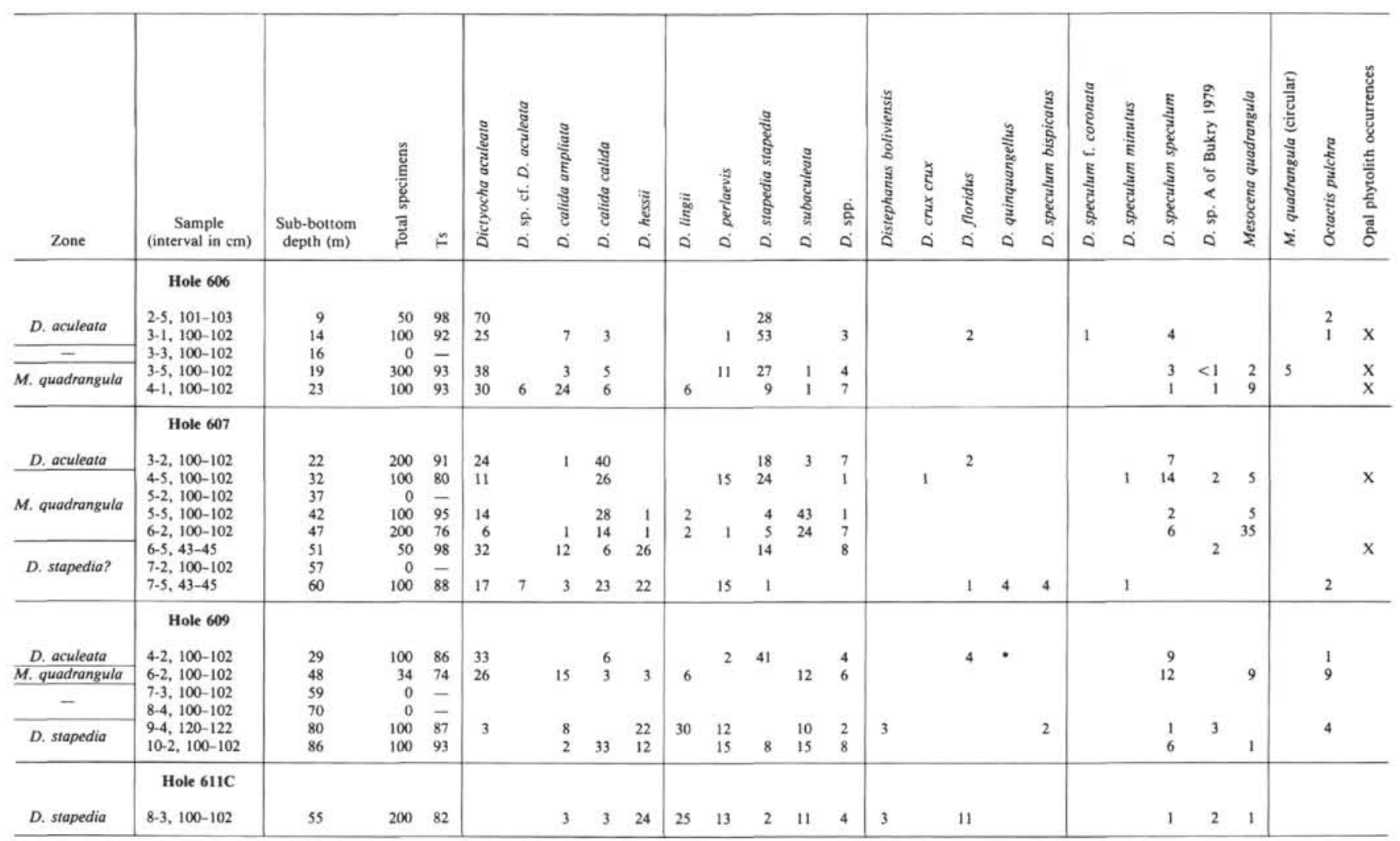

Note: $\mathrm{Ts}_{\mathrm{s}}=$ relative paleotemperature value; $\boldsymbol{\bullet}=$ recorded after count completed. 
but Distephanus speculum speculum, a key cool-water guide, is rather sparse, not exceeding $14 \%$ in any assemblage. Panicoid, chloridoid, and elongate opal phytoliths are present, suggesting some eolian sedimentation.

\section{Hole 609}

\section{$\left(49^{\circ} 52.67^{\prime} \mathrm{N}, 24^{\circ} 14.29^{\prime} \mathrm{W}\right.$, water depth $\left.3884 \mathrm{~m}\right)$}

Hole 609 is located on the eastern flank of the MidAtlantic Ridge southwest of Ireland. This location was chosen to sample the sedimentary record of paleoenvironmental shifts between subpolar and subtropical surface water masses. Silicoflagellates are sparser in the Quaternary of Cores 609-4 to 609-10 than at the more southern Holes 606 and 607, but the species arrays and dissolution thinning of specimens is similar. The Mesocena quadrangula Zone is identified only in Sample 6096-2, 100-102 cm ( $48 \mathrm{~m})$ by the co-occurrence of Dictyocha lingii and Mesocena quadrangula (Table 1). There is an unusually large concentration of $D$. lingii $(30 \%)$ with D. hessii (22\%) in Sample 609-9-4, 120-122 cm (80 m), which could be useful in regional correlation because a similar occurrence is recorded north along the Ridge at Hole 611C.

Relative paleotemperature values (Ts) are tenuous because of the low abundances of silicoflagellates at Hole 609 . The indicated values are only slightly lower than those at Hole 607 , but they diverge farther from southern Hole 606 where values of Ts $=98$ and 92 were recorded for the Dictyocha aculeata Zone and 93 for the Mesocena quadrangula Zone. Comparable values at Hole 609 are Ts $=86$ and 74, respectively.

No opal phytoliths or eolian biogenic skeletal remnants were noted in samples from Hole 609. This location was probably beyond the reach of eolian sedimentation of grassland opal phytoliths from the northwestern part of Africa.

\section{Hole 611C}

\section{$\left(52^{\circ} 50.15^{\prime} \mathrm{N}, 30^{\circ} 19.10^{\prime} \mathrm{W}\right.$, water depth $\left.3230 \mathrm{~m}\right)$}

Hole $611 \mathrm{C}$ is located on a thick sediment accumulation on the eastern flank of the Reykjanes Ridge. Coring was intended to study the marine record of Northern Hemisphere glaciation and paleoclimate. Quaternary silicoflagellates are exceedingly sparse in samples from Cores 611C-3, 611C-4, 611C-5, and 611C-6. Microscope scanning, at a magnification of $500 \times$, through 260 fields of view for Sample 611C-4-2, 100-102 cm $(15 \mathrm{~m})$ revealed only one specimen of Dictyocha aculeata and two specimens of Distephanus speculum speculum. Mesocena quadrangula was recorded in Sample 611C-8-3, 100-102 $\mathrm{cm}(55 \mathrm{~m})$. This sample is the only one examined from Hole $611 \mathrm{C}$ that could be effectively counted. The species array indicates a close correlation to Sample 609-9$4,120-122(80 \mathrm{~m})$ from the south (Table 1); abundance values of Dictyocha hessii and $D$ lingii are also so similar that close correlation is suggested. The preliminary lithologic logs show a local increase in carbonate percentage in both holes at this level, but some paleoclimatic distinctions may be suggested by the contrasting occurrences of warm-water Octactis pulchra at Hole 609 and cool-water Distephanus floridus at Hole 611C.

\section{DISCUSSION}

\section{Northern Range of Quaternary Mesocena quadrangula}

Study of Quaternary silicoflagellate assemblages from Leg 94 holes through the North Atlantic has shown definite populations of Mesocena quadrangula at Holes 606, 607,609 , and probably at Hole $611 \mathrm{C}$. This species is biostratigraphically significant because at low latitudes it became extinct between the top of the Jaramillo magnetic event $(0.91 \mathrm{Ma})$ and the base of the Brunhes Magnetic Epoch (0.73 Ma) (Hays et al., 1969; Burckle, 1977). A cross-calibration of the extinctions of $M$. quadrangula with the diatom Nitzschia fossilis, shown by Barron (1980) for low-latitude Pacific Holes 419, 422, and 428, at $0.79 \mathrm{Ma}$, was also found by Leg 94 scientists at Hole 606 (Baldauf, this volume), where a younger age of 0.64 to $0.69 \mathrm{Ma}$ is indicated. Whereas the abundance acme of $M$. quadrangula may be limited to the Jaramillo magnetic event, as shown by the $35 \%$ abundance in Sample $607-6-2,100-102 \mathrm{~cm}$, the total species range above the Jaramillo event may reflect regional ecologic or sedimentation conditions (Bukry and Foster, 1973). M. quadrangula has not been reported from north of Hole $611 \mathrm{C}$ in the Atlantic $\left(52^{\circ} 50^{\prime} \mathrm{N}\right)$, nor north of Hole $580\left(41^{\circ} 37^{\prime} \mathrm{N}\right)$ in the Pacific (Bukry and Monechi, 1985).

Although transoceanic correlation of M. quadrangula is limited by its biogeographic range, a temperate companion species-Dictyocha lingii-may extend identification of the $M$. quadrangula extinction level to higher latitudes. Dictyocha lingii disappeared at or near the extinction of $M$. quadrangula in the expanded 161-m Quaternary section at Hole 412, as well as at Holes 606, 609, 580 , and 397 (Bukry, 1979a). At latitudes of $50^{\circ}$ to $60^{\circ} \mathrm{N}$, beyond the known range of $M$. quadrangula, the extinction of $D$. lingii could prove useful by providing another paleontologic identification of the Quaternary interval from the Jaramillo Subchronozone to the lower Brunhes Chronozone.

\section{Relative Paleotemperature Values (Ts) for the North Atlantic Quaternary}

The abundances of cool- and warm-water-indicating silicoflagellates have been used in the Pacific as a convenient guide to relative paleotemperature trends (Bukry, 1981b, 1983). Calculation of Ts for Quaternary assemblages from North Atlantic DSDP Holes 397, 412, and Leg 94 holes shows very similar high values in the 90 s or high 80 s for the Dictyocha aculeata Zone.

The Mesocena quadrangula Zone of Hole 397 off northwest Africa has a short-term extremely high abundance of Distephanus speculum speculum $(63 \%)$ in midzone, which implies cold, highly fertile waters and yields a Ts of only 27 . Hole 412 contains a similar but less pronounced acme of $36 \%$, yielding a Ts of 59 . This cold $D$. speculum speculum event was not detected in the thinner sections of Leg 94. In any event, the poor preservation of silicoflagellates in many North Atlantic samples 
limits their utility in Quaternary paleotemperature comparisons.

\section{Opal Phytoliths from Leg 94}

The occurrence of opal phytoliths (chloridoids, elongates, festucoids, and panicoids) and nearshore or nonmarine diatoms (Melosira) derived from northwestern African grasslands and lake beds has been reported for DSDP Hole 397 and Hole 412 in the North Atlantic (Bukry, 1979a, b). Southern Holes 606 and 607 from Leg 94, located near Hole 412, contain the same array. Opal phytoliths were not recorded at more northerly sites from Leg 94. The accessibility of waterborne continental detritus to the Mid-Atlantic Ridge is considered slight on the basis of studies by Folger (1970). Eolian transport as far as the Azores is implied by the opal phytolith occurrences at DSDP Holes 412, 606, and 607. Dust falls from North Africa over Europe have been reported as far northwest as Ireland (Folger, 1970). Most eolian transport of opal phytoliths occurred in arid cold periods (Parmenter and Folger, 1974), but incorporation in Mid-Atlantic Ridge sediment could be time-lagged because of slumping, bottom currents, and the small (10$20 \mu \mathrm{m})$ size of opal phytoliths.

The region from Hole 607 south seems to be the area where opal phytolith occurrence could be studied in MidAtlantic cores.

\section{CONCLUSION}

Although the sparse and typically dissolution-thinned silicoflagellates from the Quaternary sediment cored on Leg 94 are difficult to study, the known northern range of Mesocena quadrangula has been extended by new occurrences at DSDP Hole $609\left(49^{\circ} 52.67^{\prime} \mathrm{N}\right)$ and Hole $611 \mathrm{C}\left(52^{\circ} 50.15^{\prime} \mathrm{N}\right)$. Mesocena quadrangula is an important low-latitude zonal marker species that became extinct after the Jaramillo magnetic event (Hays et al., 1969) and marks the top of the low-latitude Mesocena quadrangula Zone (Bukry, 1981a; see also Baldauf, this volume). The results of Leg 94 confirm that a companion species-Dictyocha lingii-disappeared at nearly the same time and can provide an alternate paleontologic guide to the interval from the Jaramillo Subchronozone to the lower Brunhes Chronozone at high latitudes beyond the range of $M$. quadrangula.

Although temperate species such as Dictyocha lingii and Distephanus floridus occur in Leg 94 assemblages, the low-latitude zonation for the Quaternary can be identified for all of the holes studied. The general low abundance levels for cool-water Distephanus speculum speculum $(\leq 14 \%)$ may, in part, reflect nutrient as well as temperature levels, because this species, which can be prolific in circumpolar and coastal upwelling areas, is notably more abundant in the Mesocena quadrangula Zone off northwestern Africa at Hole 397 (6-63\%) than at the northern Leg 94 sites.

The southern holes of Leg 94 contain opal phytoliths and nonmarine diatoms, which suggests the northern limit for eolian sedimentation from Africa along the Mid-Atlantic Ridge.
A generally sporadic preservation record for Quaternary silicoflagellates reduces the opportunity to study paleoclimatic trends with this group in the North Atlantic.

\section{SILICOFLAGELLATES CITED}

Dictyocha aculeata (Lemmermann) Dumitrică

$D$. sp. cf. D. aculeata (Lemmermann) Dumitricá

D. calida ampliata Bukry

D. calida calida Poelchau

D. hessii Bukry

D. lingii Dumitrică

D. perlaevis Frenguelli

D. stapedia stapedia Haeckel

D. subaculeata (Bukry) Bukry

D. spp.

Distephanus boliviensis (Frenguelli) Bukry and Foster

D. crux crux (Ehrenberg) Haeckel

D. floridus Bukry (includes 7- and 8-spined forms previously compared to $D$. speculum speculum)

D. quinquangellus Bukry and Foster

D. speculum bispicatus Bukry

D. speculum f. coronata Schulz

D. speculum minutus (Bachmann) emend. Bukry

D. speculum speculum (Ehrenberg) Haeckel

$D$. sp. A of Bukry 1979 a

Mesocena quadrangula Ehrenberg ex Haeckel

M. quadrangula Ehrenberg ex Haeckel (circular)

Octactis pulchra Schiller

\section{ACKNOWLEDGMENTS}

I thank Jack Baldauf, Ocean Drilling Program, College Station, TX, and John Barron, U.S. Geological Survey, Menlo Park, CA, for additional samples and valuable discussions about Leg 94. Helpful peer reviews of the manuscript were done by Paula Quinterno and John Barron, both from the U.S. Geological Survey, Menlo Park, CA. The typescript was expeditiously prepared by Dorothy Blackstock, U.S. Minerals Management Service, La Jolla, CA.

\section{REFERENCES}

Barron, J. A., 1980. Upper Pliocene and Quaternary diatom biostratigraphy of Deep Sea Drilling Project Leg 54, tropical eastern Pacific. In Rosendahl, B. R., Hekinian, R., et al., Init. Repts. DSDP, 54: Washington (U.S. Govt. Printing Office), 455-485.

Bukry, D., 1979a. Comments on opal phytoliths and stratigraphy of Neogene silicoflagellates and coccoliths at Deep Sea Drilling Project Site 397 off northwest Africa. In Luyendyk, B. P., Cann, J. R., et al., Init. Repts. DSDP, 49: Washington (U.S. Govt. Printing Office), 977-1009.

1979b. Coccolith and silicoflagellate stratigraphy, northern Mid-Atlantic Ridge and Reykjanes Ridge, Deep Sea Drilling Project Leg 49. In Luyendyk, B. R., Cann, J. R., et al., Init. Repts. DSDP, 49: Washington (U.S. Govt. Printing Office), 551-581. 1981a. Synthesis of silicoflagellate stratigraphy for Maestrichtian to Quaternary marine sediment. Soc. Econ. Paleontol. Mineral. Spec. Publ., 32:433-444.

1981b. Silicoflagellate stratigraphy of offshore California and Baja California, Deep Sea Drilling Project Leg 63. In Yeats, R. S., Haq, B. U., et al., Init. Repts. DSDP, 63: Washington (U.S. Govt. Printing Office), 539-557.

1983. Upper Cenozoic silicoflagellates from offshore Ecuador, Deep Sea Drilling Project Site 504. In Cann, J. R., Langseth, M. G., Honnorez, J., Von Herzen, R. P., White, S. M., et al., Init. Repts. DSDP, 69: Washington (U.S. Govt. Printing Office), 321342.

Bukry, D., and Foster, J. H., 1973. Silicoflagellate and diatom stratigraphy, Leg 16, Deep Sea Drilling Project. In van Andel, T. H., Heath, G. R., et al., Init. Repts. DSDP, 16: Washington (U.S. Govt. Printing Office), 815-871.

Bukry, D., and Monechi, S., 1985. Late Cenozoic silicoflagellates from the Shatsky Rise and the Northwest Pacific Basin, Deep Sea Drilling Project Leg 86: paleotemperature trends and texture classification. 
In Heath, G. R., Burckle, L. H., et al., Init. Repts. DSDP, 86: Washington (U.S. Govt. Printing Office), 367-398.

Burckle, L. H., 1977. Pliocene and Pleistocene diatom datum levels from the equatorial Pacific. Quat. Res., 7:330-340.

Folger, D. W., 1970. Wind transport of land-derived mineral, biogenic, and industrial matter over the North Atlantic. Deep-Sea Res., $17: 337-352$.

Hays, J. D., Saito, T., Opdyke, N. D., and Burckle, L. H., 1969. Pliocene-Pleistocene sediments of the equatorial Pacific: their paleo- magnetic, biostratigraphic, and climatic record. Geol. Soc. Am. Bull., 80:1481-1514.

Parmenter, C., and Folger, D. W., 1974. Eolian biogenic detritus in deep sea sediment: a possible index of equatorial ice age aridity. Science, 185:695-697.

Date of Initial Receipt: 9 April 1985 Date of Acceptance: 21 April 1985 